THE MIDDLE EAST IN THE NEW WORLD ORDER 


\section{The Middle East in the New World Order}

Edited by

Haifaa A. Jawad

Senior Lecturer in Middle East and Islamic Studies

Westhill College, Birmingham

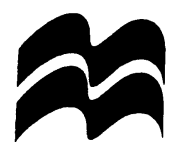


First published in Great Britain 1994 by

MACMILLAN PRESS LTD

Houndmills, Basingstoke, Hampshire RG21 6XS

and London

Companies and representatives

throughout the world

A catalogue record for this book is available

from the British Library.

ISBN 978-1-349-23558-2

ISBN 978-1-349-23556-8 (eBook)

DOI 10.1007/978-1-349-23556-8

First published in the United States of America 1994 by

ST. MARTIN'S PRESS, INC.,

Scholarly and Reference Division,

175 Fifth Avenue,

New York, N.Y. 10010

ISBN 978-0-312-12201-0

Library of Congress Cataloging-in-Publication Data

The Middle East in the new world order / edited

by Haifaa A. Jawad.

p. cm.

Includes index.

ISBN 978-0-312-12201-0

1. Middle East-Politics and Government-1979- I. Jawad, H. A.

DS63. I.N49 1994

956.05-dc20

Selection and editorial matter and Chapter 7 () Haifaa A. Jawad Chapters 1-6, 8-9 @ Macmillan Press Lid 1994

Softcover reprint of the hardcover 1st edition 1994

All rights reserved. No reproduction, copy or transmission of this publication may be made without written permission.

No paragraph of this publication may be reproduced, copied or transmitted save with written permission or in accordance with the provisions of the Copyright, Designs and Patents Act 1988, or under the terms of any licence permitting limited copying issued by the Copyright Licensing Agency, 90 Tottenham Court Road, London WIP 9HE.

Any person who does any unauthorised act in relation to this publication may be liable to criminal prosecution and civil claims for damages.

$\begin{array}{lllllllll}10 & 9 & 8 & 7 & 6 & 5 & 4 & 3 & 2\end{array}$

$\begin{array}{lllllllll}03 & 02 & 01 & 00 & 99 & 98 & 97 & 96 & 95\end{array}$ 


\section{Contents}

Acknowledgements $\quad \mathrm{vi}$

Notes on the Contributors vii

1 A Framework for Renewal in the Middle East? 1 Tim Niblock

2 Democratization in the Middle East

Heather Deegan

3 Democracy in the Maghreb

George Joffé

4 Yemeni Unification: The End of Marxism in Arabia

Gerd Nonneman

5 Security Structures in the Middle East: An Overview Anoushiravan Ehteshami

6 The Arab-Israeli Conflict and the New World Order

Emma C. Murphy

7 Pan-Islamism and Pan-Arabism: Solution or Obstacle to Political Reconstruction in the Middle East?

Haifaa A. Jawad

8 Egypt, Syria and the Arab State System in the New World Order

Raymond A. Hinnebusch

9 The Middle East after the Gulf War: The Regional

Economic Impact

Rodney Wilson

Bibliography

Index 


\section{Acknowledgements}

I would like to thank New England College (Arundel, West Sussex) for funding and supporting the Conference where most of the chapters of this book were presented. In particular, I would like to thank Dr Tamar March, Vice-President for Academic Affairs, Dudley Woodall, Director of the British Campus and the Academic Dean of the British Campus for their kind support and encouragement. Thanks are similarly due to $\mathrm{Dr}$ Paul Latawski, former colleague at New England College and coorganiser, for his efforts and support. My thanks also to each of the contributors for making this book a reality. Finally, I would like to thank Fran Hewitt for typing and circulating the invitations and most of the draft papers presented at the Conference. 


\section{Notes on the Contributors}

Heather Deegan is Lecturer in Comparative Politics at Middlesex University. She has published the Middle East and Problems of Democracy.

Anoushiravan Ehteshami is Senior Lecturer in Middle East Politics at the University of Durham. His publications include Nuclearisation of the Middle East; (co-ed.), Iran and the International Community and (with G. Nonneman) War and Peace in the Gulf: Domestic Politics and Regional Relations into the 1990s, as well as numerous articles on Gulf security and strategic affairs in the Middle East.

Raymond A. Hinnebusch is Professor of Political Science at the College of St Catherine in St Paul, Minnesota. He is the author of numerous articles on Syria and of Egyptian Politics under Sadat; he is co-author, with Alistair Drysdale, of Syria and the Middle East Peace Process.

Haifaa A. Jawad is Senior Lecturer in Middle East and Islamic Studies at Westhill College, and has taught Middle East politics at Al-Mustansriey University, Exeter University and New England College. Her publications include The Euro-Arab Dialogue (in Arabic) and Euro-Arab Relations: A Study in Collective Diplomacy as well as articles on Middle East and Islamic affairs.

George Joffé is department director at the Geopolitics and International Boundaries Research Centre, SOAS (University of London); research fellow at the University of Exeter; teaching fellow at the University of Southampton; and consultant editor for the Economist Intelligence Unit (EIU). In addition to a large number of articles on the Middle East, and on the Gulf and North Africa in particular, he has published i.a. North Africa: Nation, State and Region, and (with K. McLachlan) The Gulf War: A survey of political and economic consequences and The Gulf War: Building on the Stalemate.

Emma C. Murphy is a British Academy Post-Doctoral Fellow at the Centre for Middle Eastern and Islamic Studies at the University of Durham. She has specialised in Palestinian/Israeli political economy 
and in the phenomenon of economic liberalization in the Middle East. Among her publications is (co-ed. with Tim Niblock), Political and Economic Liberalization in the Middle East.

Tim Niblock is Professor of Middle East Studies, and Director of the Centre for Middle Eastern and Islamic Studies at the University of Durham. His publications include (ed.), Social and Economic Development in the Arab Gulf; State, Society and Economy in Saudi Arabia; (ed.), Iraq: the Contemporary State; and Class and Power in Sudan; he is co-editor, with Emma Murphy, of Political and Economic Liberalization in the Middle East.

Gerd Nonneman is Lecturer in International Relations at Lancaster University (UK), and has taught Middle East politics at the Universities of Manchester, Exeter and the International University of Japan. His publications include Iraq, the Gulf States and the War, 1980-86 and Beyond; Development, Administration and Aid in the Middle East; War and Peace in the Gulf: Domestic Politics and Regional Relations into the 1990s (with A. Ehteshami); and The Middle East and Europe: The Search for Stability and Integration.

Rodney Wilson is Senior Lecturer in Economics at Durham University, with particular expertise on the economics of the Middle East. He has written widely on issues of investment and trade in the Middle East, as well as on Islamic banking. Among his publications are (with J. R. Presley) Banking in the Arab Gulf, Politics and Economics in Jordan and (co-ed.), Islamic Financial Markets. 